\title{
Vacuum freeze-drying of sediment cores: an optimised method for preserving archaeostratigraphic archives
}

Renée Enevold ${ }^{1, *}$, Paul Flintoft ${ }^{2}$, Anna K.E. Tjellden ${ }^{1}$ $\&$ Søren M. Kristiansen ${ }^{3}$

The authors introduce an ongoing project that explores a solution for the long-term preservation of proxies in archaeological and geological sediment cores to protect unique palaeoenvironmental data. To prevent alterations of organic properties andlor fungal growth, the sediment cores are vacuum freeze-dried, allowing long-term storage at 55 per cent relative humidity (RH).

Keywords: archaeostratigraphic archive, cost-efficient storage, sediment cores, palaeoenvironmental data

\section{Introduction}

Unearthed and undisturbed sediment sequences hold substantial potential as unique stratigraphic archives that contain vital information on archaeological, climatological and palaeoecological contexts. The stored sediments and soil samples from older excavations, however, are often at risk due to changes (e.g. micromorphological structural damage and collapsed pollen) that can occur during post-excavation storage (Blake et al. 2000). The archived organic resource as a valuable future research potential contradicts the reduction in financial investment in museum and archive repositories that is leading to dwindling resources, facilities and in-house skills (Ray et al. 2013). It is therefore crucial that these storage challenges are met by technical solutions - both to secure present sediment cores and to enable an increase in contextual environmental research. This project aims to develop a preservation strategy for the long-term storage of archaeostratigraphic sediment cores that accommodates future research and, additionally, reduces energy consumption.

\section{Prevailing procedures}

Archaeological excavations and palaeoclimate field studies are often costly, long-term and complex endeavours. One strategy is to extract sediment cores to accommodate the requirements of present and future in-depth analyses (Figure 1). This method, however, leaves

1 Department of Archaeological Science and Conservation, Moesgaard Museum, Moesgaard Allé 15, Højbjerg 8270, Denmark

2 Department of Archaeology, School of Archaeology, Geography and Environmental Science, University of Reading, Earley, Reading RG6 6AX, UK

3 Department of Geoscience, Aarhus University, Høegh-Guldbergs Gade 2, Building 1671, Aarhus C 8000, Denmark

* Author for correspondence (Email: re@moesgaardmuseum.dk)

(C) Antiquity Publications Ltd, 2019

ANTIQUITY 93 370, e25 (2019): 1-4

https://doi.org/10.15184/aqy.2019.98 
excavation leaders, museums and universities with large quantities of sediment cores for storage (Harrison et al. 2016). As air-dried sediments will lose important physical properties, the prevailing procedure is to store sediment cores in cold stores. As an example, air-filled palynomorphs (microscopic plant and animal structures) tend to collapse under uncontrolled dehydration in ambient conditions (Fægri et al. 1989). Long-term storage in cold stores also results in the slow drying of the sediment and/or fungal growth on and inside the cores, as well as changes in biochemistry, bacteriology and bulk carbon properties (Clark $\&$ Hirsch 2008). The latter especially can bias radiocarbon dates, and NPP (non-pollen palynomorph) and sed $a$ DNA (sedimentary ancient DNA) analysis. As a result, comparative studies have revealed that freezing is more suitable for long-term storage of environmental samples (Sun et al. 2015). Freezing is, however, not sufficient to preserve all organic properties, even with fast nitrogen-freezing (Thieme et al. 2016); when frozen uncontrolled drying will still occur. Therefore, new solutions are urgently needed.

\section{Vacuum freeze-drying of sediment cores}

Palynological laboratories often vacuum freeze-dry small sediment samples to preserve the morphology and structure of palynomorphs, such as pollen (Tirlea et al. 2015). In preliminary studies, we have compared pollen preservation in soil samples from a vacuum freeze-dried sediment core with pollen preservation in fresh samples from the same sediment core and found a convincing equivalence. We therefore propose to introduce vacuum freeze-drying, under controlled conditions, of smaller and larger sediment cores in order to preserve several proxies, such as palynomorph morphology, sed $a \mathrm{DNA}$ and NPPs for long-term storage (Figure 2). As a prerequisite, the treatment will prevent slow drying and cracking of the sediment surfaces, microbial alterations of organic properties and/or fungal growth on the core surfaces.

We will explore the possibilities of a controlled vacuum freeze-drying of sediment cores and conduct experiments using:
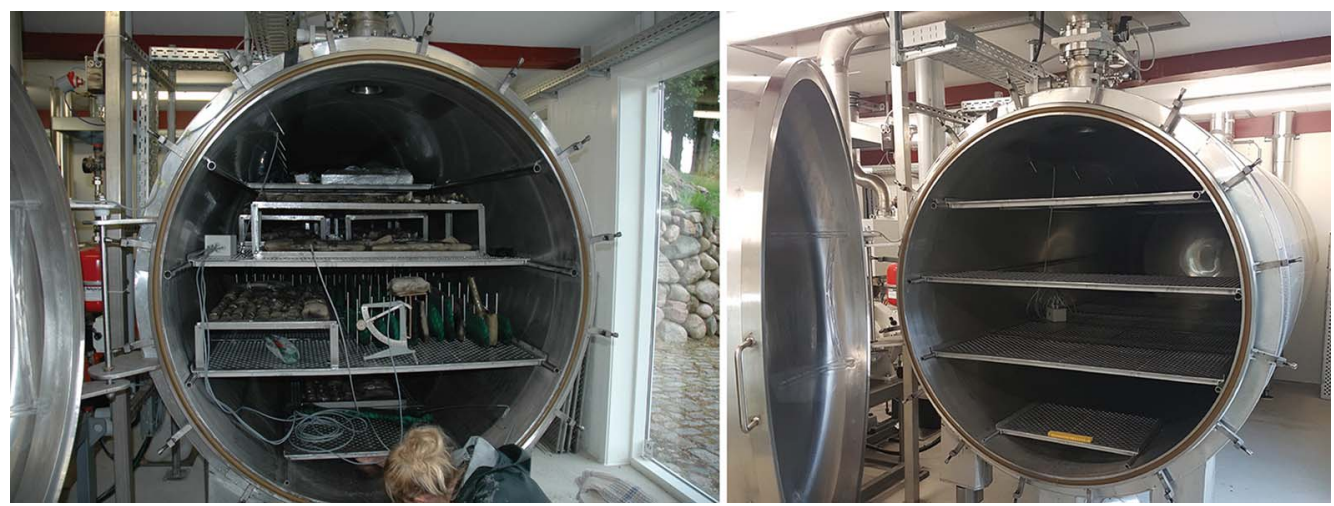

Figure 2. The large freeze-dryer at the Moesgaard Museum is ideal for the processing of sediment cores under controlled conditions such as time, pressure, water content and temperature, as well as energy consumption (photograph courtesy of the Moesgaard Museum). 
i) Highly flexible software, in terms of semi-automatic or fully manually controlled.

ii) Wireless temperature probes.

iii) Experimenting with a range of pressures, freezing temperatures and time intervals.

iiii) Different sediment types, such as gyttja, peat and sand.

Our analytical work will include a review of the North European storage facilities, longterm costs of energy consumption and the future need for archaeostratigraphical archives. The outcome of this project will facilitate future climate, palaeoecological and archaeological research, and will have the potential to be implemented on a worldwide scale. The preliminary studies are supported by Moesgaard Museum, and further funding will be applied for during the subsequent international collaboration.

\section{Acknowledgements}

The project is based at the Moesgaard Museum, Denmark, and is executed in collaboration with Aarhus University, the Danish Technological Institute and the University of Reading, UK.

\section{References}

Blake, L., K.W.T. Goulding, C.J.B. Мott \& P.R. Poulton. 2000. Temporal changes in chemical properties of air-dried stored soils and their interpretation for long-term experiments. European Journal of Soil Science 51: 345-53.

https://doi.org/10.1046/j.1365-2389.2000. 00307.x

CLARK, I.M. \& P.R. Hirsch. 2008. Survival of bacterial DNA and culturable bacteria in archived soils from the Rothamsted broadbalk experiment. Soil Biology \& Biochemistry 40: 1090-102.

https://doi.org/10.1016/j.soilbio.2007.11.021

FÆgri, K., P.E. Kaland \& K. Krzywinski (ed.). 1989. Textbook of pollen analysis. Copenhagen: Munksgaard.

Harrison, R., N. Bartolini, C. DeSilvey, C. Holtorf, A. Lyons, S. Macdonald, S. May, J. Morgan \& S. Penrose. 2016. Heritage futures. Archaeology International 19: 68-72. https://doi.org/10.5334/ai.1912
Ray, L., E. Shepherd, A. Flinn, E. Ander \& M. LAPERDIX. 2013. Funding archive services in England and Wales: institutional realities and professional perceptions. Archives and Records 34: 175-99. https://doi.org/10.1080/23257962.2013. 822355

Sun, S.Q., H.Y. CaI, S.X. Chang \& J.S. Bhatti. 2015. Sample storage-induced changes in the quantity and quality of soil labile organic carbon. Scientific Reports 5: 17496. https://doi.org/10.1038/srep17496

Thieme, L., D. Graeber, M. Kaupenjohann \& J. Siemens. 2016. Fast-freezing with liquid nitrogen preserves bulk dissolved organic matter concentrations, but not its composition. Biogeosciences 13: 4697-705. https://doi.org/10.5194/bg-13-4697-2016

Tirlea, D., A.B. Beaudoin \& R.D. Vinebrooke. 2015. Freeze-dried is as good as frozen: evaluation of differential preservation of pollen grains in stored lake sediments. Review of Palaeobotany and Palynology 215: 46-56.

https://doi.org/10.1016/j.revpalbo.2014.12.001

Received: 29 January 2019; Revised: 14 May 2019; Accepted: 23 May 2019

(C) Antiquity Publications Ltd, 2019 